\title{
To Isolate the Law: The Activity of the Jurist in Digest 9.2.27.12 and Digest 45.3.18.2
}

\author{
Edward Mussawir*
}

Griffith Law School, Griffith University, Nathan, Queensland, AUSTRALIA 4111

Ph: +61 (7) 37353667

email: e.mussawir@griffith.edu.au

\begin{abstract}
What use does the jurist have for rules and principles? What relation does he or she have to the articulation of facts? This paper considers the position of facts and rules in the casuistry of the Roman jurists. Two textual analyses of the Digest of Justinian are presented: a reading of Digest 9.2.27.12 (a statement by Ulpian on the application of the lex Aquilia to the situation of the burning of some bees) and Digest 45.3.18.2 (a consideration by Papinian of a difficult case concerning the fate of a contract made by a slave while his owner was in captivity). The paper argues that these fragments reveal the craft of the jurist in unexpected ways. What at first appears as the awkwardness of expression in them turns out to disclose a remarkable lucidity. Framed through a reading of the work of Yan Thomas, these fragments provide two nodal points for unveiling the nature of an art that does not ask what law is but seeks to isolate it in its cases.
\end{abstract}

\section{Keywords}

Jurisprudence, Roman law, jurists, casuistry, Yan Thomas, bees

Word Count 12,135

\footnotetext{
${ }^{*}$ My gratitude especially go to Professor Marta Madero who offered careful and generous insight on a previous version of this manuscript and to Professor Mary Keyes whose collegial reading and rigorous perspective on an even earlier draft helped to give it shape. I would like to also thank the anonymous reviewer for their invaluable comments and guidance in helping to bring the piece together.
} 


\section{Introduction}

\subsection{Aims. A jurisprudence, at work in two cases}

It is common to think of jurisprudence as an activity that brings us from objective facts to legal principles, from concrete cases to general rules and vice versa. We applaud it when it takes us from the solutions in individual cases to the principles and concepts that logically apply by analogy beyond them, or alternatively from what is posited as general, universal, a priori, to the particular instances that instead confirm it by way of example of the universality of what is given. In this way, practices of law - adjudication, legislation and so on - are supposed to claim the conceptual advantage of theory, abstraction, systematisation, while philosophy (moral, political and so on) gains the sense of an 'applied' science. Less is usually made, however, about an activity and a method of jurisprudence - distinct to the work of the classical Roman jurists - that has in fact tended to move in a rather different dimension: to start from the particular case and to venture to go further toward its extreme singularity, its precise uniqueness for the thought of law. Not to subsume cases under rules, but to embed the rule in the vicinity of a set of cases and to an increasingly particular, minor, subtle and technical refinement that this cases encloses. These classical jurists - unlike their modern analytical counterparts - have a much narrower interest in rules or principles than what we might at first expect, extending as Caroline Humfress puts it, only to when these rules and principles are 'at work' rather than 'idling' ': when they can be recruited in the technical elaboration and extension of their juristic constructions rather than simply 'applied' to pre-existing determinate situations. 'With an untiring patience and unvarying acumen,' Fritz Schulz observed, the classical jurists 'subject the institutions of the law to a searching casuistic examination' which 'pursues each principle to its most remote and minute consequences.' $^{2}$ It is as though the whole object of their art and the whole effort of their intellectual craft were to continually refine, not the principles, but the cases; not to describe or represent the law but to isolate it in its cases - to extract the peculiar juridical and

\footnotetext{
${ }^{1}$ Caroline Humfress, 'Telling Stories About (Roman) Law: Rules and Concepts in Legal Discourse' in P. Dresch and J. Scheele (eds), Legalism: Rules and Categories (Oxford University Press 2015), 79-104, at 98.

${ }^{2}$ Fritz Schulz, History of Roman Legal Science (Oxford University Press 1946) 126.
} 
institutional shape of things like a chemist isolates compounds and so on from more complex composites. $^{3}$

In this essay, I would like to sketch some details to two aspects to the activity of jurisprudence - the articulation of facts and rules - by taking the example of the method of classical Roman jurisprudence as a guide. The essay is presented in the form of two textual analyses of fragments preserved in the Digest of Justinian: Digest 9.2.27.12 (a statement by Ulpian on the application of the lex Aquilia to the situation of the burning of some bees) and Digest 45.3.18.2 (a consideration by Papinian of a difficult case concerning the fate of a contract made by a slave while his owner was in captivity). These fragments, as I will suggest, bear the trace of the 'craft' of the jurist in quite distinct ways: the first in the apparently odd way the jurist renders the facts of the case in question; the second in the unusualness of what appears to be certain unhelpful tangents taken in the jurists' working toward the solution to the case. While the two fragments are from a topical point of view unrelated to one another, they provide I suggest two nodal points allowing us to discover contrary to first appearances - the evidence of an unexpected creativity and elegance to the work of the jurist. It is an elegance that may be easy to miss when we insist on a conception of jurisprudence that is, to borrow Thomas Finkenauer's words, overly 'schematic and rigid' rather than 'concrete and associative'. ${ }^{4}$ Why does Ulpian - as we shall see in the first example - describe the facts of a case in such a 'surreal and bookish' way, according to Bruce W. Frier, ${ }^{5}$ as to make that case bear scarcely any resemblance to any actual social circumstance that might interest the law? Why does Papinian entertain two analogies to a supposedly hard case, in the second example, that - while complicating the problem - don't appear to be particularly fruitful for reaching a solution to it? These questions, I suggest, point to the narrowness of the terrain on which the art and inventiveness of the jurist is exercised. It is only at the surface of things that we look for an actual or natural state of affairs to which rules are meant to apply behind the 'case' as it is crafted in the hands of the jurist, just as we overstate the importance of the 'hard case' to a mode of thought that is faced

${ }^{3}$ On legal isolationism see Fritz Schulz, Principles of Roman Law (Oxford University Press 1936); Alan Watson, The Spirit of Roman Law (University of Georgia Press 1995).

4 Thomas Finkenauer, 'On Stolen Swine, Fished Fisherman, and Drowned Dogs' (2011) 7 Roman Legal Tradition 30-44, at 42.

5 Bruce W. Frier, 'Why Did the Jurists Change Roman Law? Bees and Lawyers revisited' (1994) 22 Index: International Survey of Roman Law 135-149, at 143. 
less with interpretive difficulties in finding solutions to problems, than with the techniques for bringing these problems and the outline of the legal institutions that correspond to them into ever-sharper focus. ${ }^{6}$ It is in these techniques that we can observe a lucidity to the thought of law: one which is in no way dimmed by the sometimes unexpected obscuring or denaturing of the facts of the case or, for that matter, by the introduction of certain detours in the legal avenues of argumentation.

\subsection{Methods. Fiction and casuistry in the Roman Law scholarship of Yan Thomas}

Before introducing the two cases in question, it is worthwhile making some remarks on the method that informs the analysis of them. My approach in revisiting these sections of Roman civil law attempts to follow some avenues opened by the work of Yan Thomas, an author who, before his death in 2008, had taken the affiliation between jurisprudence as the thought of law, and the study of Roman law as the historical object through which the transmission of this thought is still possible, with an unparalleled ingenuity. It is far beyond the scope of this piece to provide a detailed sketch of the extent of Thomas's intervention in the study of Roman law and the challenge that his work has proven capable, as Marcela Iacub acknowledges, of putting to the contemporary humanities and legal philosophy in general. ${ }^{7}$ Alain Pottage writes that the influence of his work was based on the thoroughgoing originality of his studies of certain institutions of Roman law' which 'entirely transformed an understanding based on more than a century of heavyweight historical and philological scholarship. ${ }^{8}$ From a legal philosophical perspective, the originality of this work can be broadly connected, as Marta Madero has observed, to two unique conceptual affinities: an affinity for legal fiction over and above the 'axiology of legal principles in which liberal ideology finds its metaphysics', and a close attention and privilege ascribed to casuistry as a

\footnotetext{
${ }^{6}$ Alain Pottage, 'Law After Anthropology: object and technique in Roman Law' (2014) 31 Theory, Culture and Society 147-166.

${ }^{7}$ Marcela Iacub, 'Yan Thomas, la morte d'un grande maître du droit', Libération, Paris, 23 September 2008. Accessed 19 October 2013 at http://www.liberation.fr/tribune/2008/09/23/yan-thomas-la-mort-d-un-grandmaitre-du-droit 545040. Collections devoted to the legacy of Thomas's work are found in Paolo Napoli (ed), Aux origines des cultures juridiques européennes. Yan Thomas entre droit et sciences sociales (Rome, École française de Rome 2013), and Emanuele Conte, Marta Madero and Alejandro Morin (eds), 'Casuística y ficción: homenaje a Yan Thomas' (2014) 11 GLOSSAE: European Journal of Legal History.

${ }^{8}$ Pottage, 'Law After Anthropology' (n 6), 150.
} 
lens through which law and history are seen through their cases and concrete problems more than through doctrinal development. ${ }^{9}$

Both of these ideas express something of the commitment and conviction in Thomas's work, as Olivier Cayla, Jacques Chiffoleau, Marie-Angèle Hermitte and Paolo Napoli write in their tribute to their friend and colleague, that there exists 'a particular way for the jurist to act upon the world'. ${ }^{10}$ Legal fiction for instance offers us a glimpse into the nature of a particular craft, a particular way of making things that is distinctive to the jurist and that cannot simply be explained by the textual, social or institutional convenience it serves. It is fiction more than anything else, in Thomas's approach, that allows us to witness the limits of the inventiveness of legal thought and the effects that law as a technique has on the world: precisely the distance that it creates and maintains between itself and that of 'truth', 'nature' and 'reality'. 11 Thomas allows us to see in fiction the extent to which law constitutes something more than a reflection of a social practice. It doesn't just place its stamp on a social reality that exists outside it. Rather it makes up an institutional technique placing a wedge between artifice and reality and widened this gap even further. For Thomas, the realm of legal fiction - basing the law on a set of facts one acknowledges to be false - casts a clear light on a juristic art or technique that is characterised less by its conservativeness with respect to the law than its remarkable 'subversiveness' with respect to the facts: its inclination to make the facts undergo certain 'distortions' in order to 'exercise a hold on them'. ${ }^{12}$ The extent of this technique is often occluded, he reminds us, when we fail to take account of a long medieval attempt to tether legal fiction to the dictates of a transcendent 'truth of nature'. This attempt to rein the 'empire' of fiction to truth is one that finds itself more or less completed in modern law. Thus, for Thomas, the task of observing today in the classical

\footnotetext{
${ }^{9}$ Marta Madero, 'Penser la tradition juridique occidentale. Une lecture de Yan Thomas' (2012) 67(1) Annales Histoire, Sciences Sociales 103-133, at 103. Unless otherwise indicated, all translations to English in this work are my own.

${ }^{10}$ Olivier Cayla, Jacques Chiffoleau, Marie-Angèle Hermitte and Paolo Napoli, 'Yan Thomas - Hommages', CENJ Website. Accessed 16 February 2018 at http://cenj.ehess.fr/index.php?292.

${ }^{11}$ Yan Thomas, 'Fictio legis: L’empire de la fiction romain et ses limites médiévale' (1995) 21 Droits 17-63, also published in Yan Thomas, Les opérations du droit, (Seuil/Gallimard 2011), 133-186.

12 Thomas, 'Fictio legis' (n 11), at 19.
} 
texts (where the activity is grounded by no such limits) the difference between the evidence of facts and the product of a definite juristic technique, is all the more profound. ${ }^{13}$

Thomas's reading of the history of the Roman legal tradition is similarly characterised by his affinity for the methods of legal casuistry. Casuistry can be described as an approach to jurisprudence in which, to borrow Dario Mantovani's description, 'no abstract construction can be dissociated from the case for which it had been thought'. ${ }^{14}$ For Thomas, casuistry is an understanding of jurisprudence as a 'case-law', but one that obeys 'less the force of precedent ... conforming with a normative model which vertically subsumes the case under norms' and seeing the legal principle emerge from the rationale of individual judgments, than one that serves 'to extend the network of analogies... in order to associate institutions or things'. ${ }^{15}$ Thus, unlike English common law, in which the case is only the instance of deriving principles from concrete decisions, the casuistic method of the classical Roman jurists, as Tomasz Giaro also notes, treats the concrete matter of the case as an occasion for a

\footnotetext{
${ }^{13}$ See Thomas, 'Fictio legis' (n 11); Yan Thomas, 'Les artifices de la vérité en droit commun médiéval' (2005) 175-176 L'Homme 113-130.

${ }^{14}$ Dario Mantovani, 'Le détour incontournable: le droit romain dans la réflexion de Yan Thomas' in P. Napoli
} (ed), Aux origines des cultures juridiques européennes. Yan Thomas entre droit et sciences sociales (Rome, École française de Rome 2013) 21-36 at 36.

${ }^{15}$ Yan Thomas, “L'extrême et l'ordinaire. Remarques sur le cas médiéval de la communauté disparue' in J-C. Passeron and J. Revel (eds), Penser par cas (EHESS 2005) 45-73 at 72, also published in Thomas, Les opérations du droit (n 11) 207-237. On the philosophical purchase of legal casuistry consider the remarks on 'jurisprudence' by Gilles Deleuze who considered it in terms of an 'invention of right' that, like life, goes 'case by case', dismissing the universal in favour of 'emissions of singularities'. See e.g., Gilles Deleuze, Two Regimes of Madness: Texts and Interviews 1975-1995, D. Lapoujade (ed), translated by A. Hodges and M. Taormina (Semiotext(e) 2006), at 350; Gilles Deleuze, Empiricism and Subjectivity: An Essay on Hume's Theory of Human Nature, trans. Constantin V. Boundas, (Columbia University Press 1991); Gilles Deleuze, L'Abécédaire de Gilles Deleuze, avec Claire Parnet (Editions Montparnasse 2004). On the interpretation of Deleuze's philosophy in the context of jurisprudence see e.g., Nathan Moore, 'Icons of Control: Deleuze, Signs and Law' (2007) 20(1) International Journal for the Semiotics of Law 33-54; Alexandre Lefebvre, The Image of Law: Deleuze, Bergson, Spinoza (Stanford University Press 2008); Laurent de Sutter, Deleuze: la pratique du droit (Michalon 2009); Rosi Braidotti, Claire Colebrook and Patrick Hanafin (eds), Deleuze and Law: Forensic Futures, (Palgrave Macmillan 2009); Laurent de Sutter and Kyle McGee (eds), Deleuze and Law (Edinburgh University Press 2012); Jamie Murray, Deleuze and Guattari: Emergent Law (Routledge 2013). 
creative and systematic reflection. ${ }^{16}$ In Thomas's hands, this method is also a refutation of a jusnaturalism that would treat the work of the jurist as an enterprise that, unconstrained by legalism, serves universalisable natural ends. Instead Thomas invites us to inhabit the local, provisional and makeshift contours of their constructions. He often shows, by guiding us back to the immanent, pragmatic terrain of the cases on which the jurists exercised their craft, just how far our reliance upon certain givens and commonplaces in contemporary legal thinking separates us from the true inventiveness of our legal heritage. The terrain of casuistry, "where the argumentation is in service of a particular decision and where it is constrained by the imperative of its practical effects ${ }^{17}$, strikes Thomas as a far better site than philosophical and ideological critique for encountering the true depth to the thought of law. That thought is not exhausted by a decision-making activity. Casuistry rather secures for thought a terrain of creativity where one encounters the 'plastic point of view' ${ }^{18}$ of juridical forms and the 'irreducibility of the gap that separates the virtual and the actual plane over which the rules of the law and facts of the case are simultaneously placed.' ${ }^{19}$ As MarieAngèle Hermitte and Paolo Napoli observe, Thomas's approach to casuistry amounts to a 'rigorous enterprise of documenting the historical misfortunes of this structural gap between fact and law'. ${ }^{20}$ The casuist removes any transcendentalism of the rule over facts, or of nature over artifice. The cases themselves are the well-crafted means by which an immanent test of the world of rules or principles is carried out.

These broad directions in Thomas's work - given only a brief outline here - are what I have drawn upon most directly in approaching the texts in question to try to uncover a significance in them that may be relevant for the contemporary understanding of jurisprudence as a mode of thought. Thomas's insights in particular invite us to cast a different emphasis in jurisprudence on the presence of 'facts' and 'rules': one that takes us to a new appreciation for the work of jurists, and the classical Roman jurists in particular, whose

16 Tomasz Giaro, 'Über methodologische Werkmittel der Romanistik' (1988) 105(1) Zeitschrift der SavignyStiftung für Rechtsgeschichte: Romantische Abteilung 180-262, at 212-215.

${ }^{17}$ Yan Thomas, 'Le sujet de droit, la personne et la nature: sur la critique contemporaine du sujet de droit' (1998) 100 Le Débat 85-107, at 85.

${ }^{18}$ Yan Thomas, 'Présentation' (2002) 57(6) Annales Histoire, Sciences Sociales 1425-1428, at 1426.

${ }^{19}$ Thomas quoted in Mantovani, 'Le détour incontournable' (n 14), 26.

${ }^{20}$ Marie-Angèle Hermitte and Paolo Napoli, 'Préface' in Y. Thomas, Les opérations du droit (n 11), 7-15, at 15. 
significance Thomas does not just update for contemporary thought but indeed completely renews on a thoroughly radical and anti-dogmatic terrain.

\subsection{Materials. Digest 9.2.27.12 and Digest 45.3.18.2.}

I have selected the two passages in question (Digest 9.2.27.12 and Digest 45.3.18.2) not because these two in particular occupy a significant place in Thomas's own work nor to add new material or a new historical context to their interpretation. Rather, I would like to show how the arrangement of each fragment betrays a possibly under-appreciated aspect to the activity of the jurist: one that tends, in many other ways, to go easily unnoticed but which is brought to light more clearly through the tools that Thomas's work provides. What I would like to bring out in the interpretation is that, in each case, it is precisely what might at first appear as the awkwardness of expression or presentation in them that may in fact on closer inspection turn out to enclose what is most lucid and creative in their perspective on law.

In both of these cases I suggest, the contemporary interpreters of the juristic activity in question - Bruce Frier in the first example and Alan Watson in the second - appear to give it what we could call a certain 'subsumptive' or 'representational' inflection: a preference for the proposition of rules, judgments and their systematisation that is meant to underlie legal order in general and jurisprudence in particular over and above the pure occasion that a 'case' presents for the imagination and articulation of legal thought. What the jurist is meant to do, with whatever means available, is to expertly 'subsume' the case under adequate rules and principles and in doing so thereby accurately 'represent' the law. My analysis however tries to resist this approach and also therefore the temptation to look for possible alterations or imperfections in the text or in the soundness of the reasoning. Instead, the unusual form of expression in each fragment - the apparent attenuation in one, as we shall see, and the apparent detour or over-elaboration in the other - I suggest can be treated as the sign of an extreme care taken by the jurist for the thought of law and an approach that attempts not just to represent this thought, but to 'isolate' it. Rather than merely tracing the lines between the particular case on one hand and abstract universals and general rules on the other, the work of the jurist - to follow the insight of Yan Thomas - shows itself to be an immanent and thoroughly inventive art: attuned very precisely to the nature of its object. 


\section{Analysis I. Opaque facts and lucid law. The juridical function of the bees in Digest 9.2.27.12}

\subsection{If when my bees had flown to yours, you burn them...}

'If, when my bees had flown to yours, you burn them, Celsus says that an action on the lex Aquilia lies.' ${ }^{21}$

What sense can be made of the formulations of the jurist Ulpian here in this rule about the possibility for an action under the lex Aquilia, an ancient Roman plebiscite (c 287 BCE) imposing reparation for certain kinds of unlawful harm, for the situation of some bees that have been burnt? The particular chapter of the lex Aquilia in question here deals with harm done to property (other than the killing of slaves and cattle) and imposed liability on whoever had unlawfully 'burned, broken or spoiled'22 the property of another. The fragment appears among a series of case-scenarios in which Ulpian explores the meaning of various part of this statute. Among these cases, the statement in relation to the bees stands out as being particularly unusual. What do the formulations 'my bees', 'to yours' and 'you burn them' mean exactly? The reference to any actual or likely state of affairs in the fragment seems especially tenuous or opaque. Is Ulpian speaking of one to two bees or a whole swarm? Does 'to yours' refer to the bees joining and merging with your own swarm or hive of bees? Or does it just mean flying onto your property or settling into your trees? What is the precise context and motive for 'burning' bees? If there is a particular or typical case intended by this example, we find it to be unusually difficult to envisage. Bees, we might be told by naturalists, don't typically fly off and join another swarm on their own accord: not without artificially removing a queen for instance. But if all that is meant by the statement is that the bees flew off from one person's property and onto a neighbour's property, then why - putting

21 Digest 9.2.27.12 (Ulpian, Edict, book 18). Unless indicated otherwise, all references in this paper to Justinian's Digest in the English translation are taken from Alan Watson (ed.), The Digest of Justinian Vol 1-4 (University of Pennsylvania Press 1998). The translation by Colin Kolbert in Watson's edition gives: 'If, when my bees had flown off to join yours, you burn them out, Celsus says that the action on the lex Aquilia lies.' It thus tends to privilege the view of the merging of two swarms. I have preferred a slightly plainer rendition, in order to maintain the succinctness of the phrase and the ambiguity of meaning in the original.

${ }^{22}$ The actual terms are 'usserit fregerit ruperit iniuria'. In Digest 9.2.27.13 Ulpian notes that the statute says 'ruperit [break or rend asunder]; but almost all the early jurists understood the word to mean corruperit [spoil]'. 
corruptions of the text aside - would the writer not bother to waste a word to specify that fact? And at the end of the day, if the intended case is so truncated and so poorly defined, what is the point of including it within a commentary on the extent of the application of the lex Aquilia? Can we dismiss it simply as a certain awkward phrasing of the point by the jurist? Can we just put it down to a poor understanding on the lawyer's part of the typical behaviours of bees and the general troubles and concerns of beekeepers?

No. At base, these questions express more of a narrow preoccupation about the interpretation of law when it is matter of understanding the kind of regulation it performs on society, than an appreciation for the preoccupation (aesthetic, scientific and so on) of the jurist him or herself. We can be easily forgiven for thinking that the facts here are simply poorly described. We can be forgiven for assuming that what the jurist should have been aiming to do is to elucidate by way of clear examples, the structure of the general rule of liability under the statute; to outline the cases that are commodious to the social purpose that the law is meant to serve as examples that are commonly encountered in practice and in which the rule can be distinctly understood and easily brought to mind. The articulation of the case should, in short, reflect a social reality that the law aims to govern.

Now it is easy to ignore here the precise 'work' that the jurist performs on his material not merely in registering a social or factual reality and ordering it by way of rules, but in remodelling or denaturing the facts themselves so that they may enter the preciseness of the thought of law. The fragment is not just the description of a law. It doesn't just lay down a rule. It is the product of a certain art: one that may not necessarily be crafted with the intention of being read easily, or even to accord with a particular commonplace view of reality. Ulpian's text about the bees can appear to us very differently when what we expect to see in it is not necessarily the laying down of a general rule and its application or explanation in a factual example, but rather the pursuing of a kind of scientific method of experimentation: a form of 'testing' the rule by bringing it into the vicinity of a tightly crafted case. In that case, the unusualness that we find in the facts as described, can be the evidence not simply of some state of error or disrepair, but of a thought that persists on the page of law and which resists being reduced to the representation of some rule. Roman jurisprudence, for example, is a work that is tightly linked to the verbal forms and syntax of legal action. Thus, when we encounter a peculiar form of words in the legal literature, it is unlikely that this can be put down to any 'muddling' of terms. There is reason instead to entertain the possibility that this odd expression may in fact be the product of - rather than a departure from - the 
precision required by this procedural literacy of the jurist. To understand the meaning of the fragment then, we should attend as closely as possible to the problem of law that the formulation - however unusual - corresponds to within its sober economy of expression. How and why, we might ask, do these bees becoming exacting in the mind and work of the jurist? It is necessary first to consider the function and role that they play not necessarily as external representatives of a nature intended to be governed by law, but in the precise juristic outline in which they appear.

\subsection{The apian shape of possession}

In the Roman juridical literature - keenly examined by some modern authors ${ }^{23}$ - bees tend to be prone, as E.J. Cohn puts it, to 'furnish lawyers with attractive little problems ${ }^{24}$ and in particular to help trace the boundaries between various forms of ownership. The extended passage for example, from which our fragment appears to be an abbreviation, ${ }^{25}$ recorded in Collatio 12.7.10, ${ }^{26}$ a pre-Justinianic compilation comparing Mosaic and Roman laws, makes explicit mention of the opposing juristic viewpoints on the legal meaning of bees: a distinction between the view of Proculus who thought that the action under the lex Aquilia did not lie because there was no property in the fleeing bees, being neither domesticated nor kept enclosed, from that of Celsus who thought on the contrary that the action did lie since bees were considered to be 'fruits', and like doves to have a mind to return (animus revertendi). ${ }^{27}$ This discussion accords with many other appearances of bees in the juridical

${ }^{23}$ See E. J. Cohn, 'Bees and the Law' (1939) 55 Law Quarterly Review 289-294; G. W. Paton, 'Bees and the Law' (1941) 3 Res Judicatae 22-27; Bruce W. Frier, 'Bees and Lawyers' (1982) 78(2) The Classical Journal 105-114; Frier, 'Why Did the Jurists Change Roman Law?' (n 5).

${ }^{24}$ Cohn, 'Bees and the Law' (n 23), 289.

${ }^{25}$ It appears that the authenticity of the unusual phrasing ('when my bees had flown to yours, you burn them') in the fragment is supported by the fact that it was reproduced in the same form in both the Digest and the Collatio. It is also probable that the Digest fragment was included in an abbreviated form by the compilers so as either to distil the main idea in it or to remove the legal doubt associated with the view of Proculus. In either case, it appears that part of the brevity of the fragment may be owing not just to the mind of Ulpian himself but also to later juristic editing.

${ }^{26}$ See M. Hyamson (ed), Mosaicarum et Romanarum Legum Collatio (Oxford University Press 1913) 120-121.

${ }^{27}$ It should be noted that Bruce W. Frier translates the term 'fruits' (fructui) in the fragment as 'source of profit'. Frier, 'Bees and Lawyers' (n 23), 112. Ariana Pretto-Sakmann aptly points out that this tends to ignore the fact that the term 'fruits' (fructui) is normally read as having a technical meaning in Roman law. The conclusion is that bees may have become an exceptional case because of a cultural tendency to view them sometimes more as 
texts where they enter the casuistic frame precisely in order to test the contours of certain kinds of acquisition or occupation of property. Bees serve to qualify in certain ways the modes by which one is said to acquire or lose possession and ownership in things that are first considered no-one's, res nullius.

In Digest 41.1.5 for instance (from book 2 of Gaius's Common Matters or Golden Things), the example of bees is used to navigate the boundary between two theories of acquisitive prescription: on the one hand that in which a wild animal will be considered 'ours' if it has been wounded to the point that it can be captured, so long as we are still in pursuit of it (the view favoured by Trebatius), the other (favoured by the majority) in which an actual capture is required in order to have a better title than any other would-be acquirer. Gaius notes - somewhat obliquely in relation to this initial debate - that for bees which are treated as wild by nature, when 'a swarm flies away from our hive' it will still be 'ours so long as we have it in sight and its recovery is not difficult; otherwise, it is open to the first taker.' Bees therefore evoke the idea of a form of possession that is not absolute. They give us a legal figure characterised by its susceptibility to return to nature, to regain its natural liberty and be claimed by the 'first taker', but also one which extends in a certain way beyond boundaries by a tendency to return. The bees trace a form of possession which can be maintained in a sort of pursuit where other claims to the animal are temporarily held at bay, and a shape of ownership that extends no further than this elastic, roaming possession. Yan Thomas explains the remarkable way in which the Roman jurists were capable in this area of filing a whole philosophical discourse on 'nature' and 'natural right' back within the narrow institutional frame of civil law. ${ }^{28}$ They treated the so-called 'natural liberty' that the wild animal is supposed to regain by fleeing one's capture as itself a neat but purely juristic outline for qualifying an institutional arrangement: namely the species of possession known as pro suo (acquiring for oneself, that is an appropriation that isn't obtained derivatively, by delivery or dereliction and so on) which could, along with a number of other modes of acquisition, accrue with the passage of time into a full ownership by usucapio. Nature is not an external

'crops' than as 'wild animals'. See Ariana Pretto-Sakmann, “'You Can Never Tell With Bees”: Good Advice From Pooh for Students of the Lex Aquilia' in A. Burrows and A. Rodger (eds), Mapping the Law: Essays in Memory of Peter Birks (Oxford University Press 2006), 475-496, at 491.

${ }^{28}$ Yan Thomas, 'Imago naturae. Note sur l'institutionnalité de la nature à Rome' in Théologie et droit dans la science politique de l'État moderne (Collection de l'École Français de Rome 147, 1991), 201-227. 
referent here, Thomas informs us. It doesn't provide a 'vague reference to the idea that institutions have to conform to an order that transcends them', but rather a 'mirror' of the law, an 'image of institutions' which are also forged by it and often extended by it. ${ }^{29}$

We get a clearer view of the significance of the bees in our original passage then when we acknowledge the originality to the institutional meaning and technical work that the jurist reserves for them. It is not necessarily anything natural to the bee that makes it suitable for the juristic construction in question. Rather the jurist carves out a highly original meaning for nature in the figure of some bees: their meaning as institution, which we find is capable of outlining at an abstract level the precise contour to a mode of possession and appropriation. When Ulpian refers to the example of bees (built upon the discussion of Celsus and Proculus) in the context of the lex Aquilia, what is important is that enough of this juridical and casuistic figure of the animal can be borrowed from the law concerning the acquisition of ownership for the purposes of articulating the interpretive limits of the lex Aquilia. But what is equally important is that this analysis at the same time is able to sufficiently distinguish itself from the other (possessory) context. ${ }^{30}$ It has to somehow avoid pre-empting or subsuming the whole jurisprudence on acquisitive prescription within the narrow point of statutory interpretation that the discussion of the lex Aquilia concerns. ${ }^{31}$ There is of course an ambiguity over whether one still has any relevant form of possession or ownership over some bees that have flown away for the purposes of a law that requires payment to owners of property against those who, in the words of the statute itself, have done 'damage by

${ }^{29}$ Thomas, 'Imago naturae. Note sur l'institutionnalité de la nature à Rome' (n 28), at 219.

${ }^{30}$ We can't be certain about the respective historical state of development of each of these two areas of law. However, the possessory context in which Gaius mentions bees is likely, due to his reference to Trebatius in Digest 41.1.5.1, to have existed at the latest by the first century BC, while the Aquilian context - if we can take Proculus and Celsus to be the first representatives of this particular debate - would be from the early classical period, either the first or early second century AD. See Frier, 'Why Did the Jurists Change Roman Law?' (n 5), at $145-146$ [fn 9].

31 Thomas Finkenauer seems to make a similar point in relation to Digest 41.1 .44 (where Ulpian relates a case discussed by Pomponius of a swineherd whose pigs were stolen by some wolves and whose neighbour recovered the pigs by use of his dogs). Finkenauer writes that: 'Pomponius does not simply apply well-known principles - wild animals becoming ownerless when gaining their natural freedom, domestic animals continuing to be owned until their death - but he tries to approach the problem of his case - namely the collision of the owner's interest in continuity and rescuer's interest in recompense - from several points of view.' Finkenauer, 'On Stolen Swine, Fished Fisherman, and Drowned Dogs' (n 4), 42. 
unlawfully burning, breaking or spoiling' (damnum faxit, quod usserit fregerit ruperit iniuria). ${ }^{32}$ But the answer to that ambiguity is evidently not - I would argue - to step outside the institutional realm of law to consider such aspects as the natural propensity of bees, the economic implications for beekeepers and so on. Nor is it - one should add - to subsume on the other hand the whole question of what can be considered 'property' subject to the protection in the lex Aquilia under some naturalistic philosophy drawn in reverse from the casuistry of acquisitive prescription. The challenge is rather to meet the ambiguity one finds in the immediate institutional field with an adequate juridical abstraction drawn from another and to find in the association of these ideas a way of deepening the thought that underlies them.

\subsection{Burned bees: a procedural estimation of value}

It is worth mentioning at this point the interpretation of the passage that is offered by Bruce W. Frier in his two essays 'Bees and Lawyers' and 'Why Did the Jurists Change Roman Law? Bees and Lawyers revisited'. ${ }^{33}$ Frier puts Celsus's approach to the problem, which he champions, down to an astute understanding of the social value of beekeeping on the part of the jurist and a flexibility with respect to the function of the rules, maintaining that it matters less in the context of this problem whether the bees "belong" (in one sense or another) to their owner' than the fact that 'their owner is a beekeeper, and beekeeping is a desirable and productive activity' ${ }^{34}$ Frier's point of view is built on a hypothesis about the nature of legal change and the flexibility of legal casuistry. ${ }^{35}$ However it is also premised on certain assumptions about the form of evaluation that law is capable of conducting in relation to the 'things' of which it speaks. From his perspective, what the fragment on the bees reveals primarily is that the Roman jurists, far from being caught in a thoroughly professional and artistic insularity or from applying rules drawn from nature, were in fact influenced to a large degree by the necessities of their broader social and economic contexts. The point, Frier explains is this:

\footnotetext{
32 This phrasing, given by Ulpian in quoting the third chapter of the lex Aquilia in Digest 9.2.27.5, is generally taken to be a genuine rendition of the original.

${ }^{33}$ Frier, 'Bees and Lawyers' (n 23); Frier, 'Why Did the Jurists Change Roman Law?' (n 5).

${ }^{34}$ Frier, 'Bees and Lawyers' (n 23), 112

${ }^{35}$ Frier, 'Why Did the Jurists Change Roman Law?' (n 5), 143-145
} 
Juristic categories (like 'wild' and 'domesticated') often look at first sight like neutral descriptions of reality, descriptions drawn from everyday experience. However, in fact such categories are not neutral, but are charged with the meaning they receive from the legal rules that utilize them. In turn, these legal rules rest ultimately upon the bedrock of 'public policy', the final arbiter to which 'hard cases' must be referred. ${ }^{36}$

What the fragment shows us, in Frier's view, is the way the law evolves and establishes new principles to meet the needs of its society and changing circumstances. Even the Roman jurists then, he can suggest, who are normally characterised by the steadfastness in the independence of their craft, the strictness with which they held to their science and to the worth of their jurisprudence as an art for its own sake, can be depicted here as being directed, in the same way that any good common lawyer ultimately is, by judicious policy choices in the penumbra of their positive rules. Not even the pure artistic rigour of the Roman jurist can insulate itself from the need for law, at the end of the day, to be 'actually socially adequate for its time and place'. ${ }^{37}$

Of course, this hypothesis draws the figure of the bees in Ulpian's fragment squarely toward the context of a certain economic reality, the 'productive' human activity of beekeeping in the Roman world. The idea is a straightforward one: bees have to fly free to some extent so that they become 'productive' animals (i.e. making honey) for their owners. Therefore, there is a good policy reason for law to 'protect them in their flight', ${ }^{38}$ unlike many other 'wild' animals whose movement beyond the immediate possession of their keepers serves no productive purpose. This view however ascribes to the jurist an economic valuation of the bees, in the name of a contextual reading of the law, that is no-where explicitly supported in the juridical literature itself. As Arianna Pretto-Sakmann observes, Frier's view of the bees is one that tries to make their "nature square with the law. ${ }^{39}$ It places significant stock in the universality of values tied to a determinate human economy in the possession of bees, but in doing so thereby potentially ignores the distinct independence that the animal can acquire in a jurisprudence that in fact has little interest in things as objects of nature, as economic means of production or as things-in-themselves. We should be wary in this way of dismissing too quickly the characteristic aversion that the jurists appear to show

\footnotetext{
${ }^{36}$ Frier, 'Bees and Lawyers' (n 23), 106.

${ }^{37}$ Frier, 'Why Did the Jurists Change Roman Law?' (n 5), 144.

${ }^{38}$ Frier, 'Bees and Lawyers' (n 23), 112.

${ }^{39}$ Pretto-Sakmann, 'You Can Never Tell With Bees' (n 27), 493.
} 
toward rationalities based merely in economic and public policy concerns. And we should be wary too of being over-confident in our own estimation of 'values' as to put more weight in the notion of beekeeping as a 'productive activity', serving a valid 'human' interest, than to consider the detailed and detached technical reflection that the jurists themselves produced on as focused and as complex a terrain as how value and loss were to be assessed under the lex Aquilia.

Consider, on this last point, the much debated element of the third chapter of the lex which provides for reparation according to the measure of 'how much the thing will be in the nearest 30 days' (quanti ea res erit in diebus triginta proximis). The modern interpretations of this provision, it is worth noting, are wildly divergent. David Daube for example criticised the prevailing view that the damages were to be calculated based on the highest value of the property itself in the 30 days prior to the damage, arguing that if that were the case there would be no distinction in terms of the calculation of damages between minor injury to a thing and complete destruction of it. ${ }^{40}$ A person having done some minor damage to property might just as well 'finish the job' since in either case he or she would be liable for the full value of the property. He thus thought that the time rule was actually meant to be read forwards so that what the law accounted for was such loss as accrued within the 30 days following the damage. Others have followed, to varying degrees, the 'orthodox' view that it referred to the (highest) value that the damaged thing had in the 30 days preceding the wrong, qualifying it with the suggestion that the law only covered damage to a thing that was either absolute or very serious, so that the value of such damage largely approximated the entire value of the thing itself. ${ }^{41}$

Even here, however, the debates are set on a rather confusing path when they seek to interpret the law through methods of evaluation of 'things' divorced from the procedure and

\footnotetext{
${ }^{40}$ David Daube, 'On the Third Chapter of the Lex Aquilia' (1936) 52 Law Quarterly Review 253-268.

${ }^{41}$ For selection of work addressing this theme, see H. F. Jolowicz, 'The Original Scope of the Lex Aquilia and the Question of Damages' (1922) 38 Law Quarterly Review 220-230; Daube, 'On the Third Chapter of the Lex Aquilia' (n 40); Geoffrey MacCormack, 'On the Third Chapter of the Lex Aquilia' (1970) 5(1) Irish Jurist 164178; John M. Kelly, 'Further Reflections on the "Lex Aquilia"' in L. Aru (ed), Studi in onore di Edoardo Volterra, Vol. 1 (A. Giuffrè 1971) 235-241; Raymond Westbrook, 'The Coherence of the Lex Aquilia' (1995) 42 Revue internationale des droits de l'antiqué 437-471; Reinhard Zimmermann, The Law of Obligations: Roman Foundations of the Civilian Tradition (Oxford University Press 1996).
} 
casuistry that takes hold of them. There is a tendency to see law as secondary to values tied somehow to the metaphysics of objects, rather than as creative of the very values that inhere in legal 'things'. It is true for instance that the Roman jurists did not think of a res, 'thing', as separate from the procedure in which it was held as an object of contestation. The term res, as Yan Thomas has also pointed out, is at once a 'thing' as well as a 'contested matter': the value it represents in a proceedings. ${ }^{42}$ When the law refers to the amount the thing will be here, it is referring therefore not necessarily either to an absolute or a market value of some tangible object, but to a judicial procedural estimation in relation to which a judge can decide this particular matter: it alone and not anything else. ${ }^{43}$ It is not the thing itself that must be valued (a comparison of what it was worth 'before' and 'after' it was damaged). The thing is itself the identity in its value: what this wrong as alleged represents in the estimation of the judge. The reference to 30 days seems likely to be simply a proximity in time to the wrong to which the imaginary time of reckoning the value of the matter is directed.. When the jurist Paul remarks rhetorically in Digest 9.2.24 (Edict, book 22), 'what wound are we to value, or to what time shall we reckon back?' in reference to the situation where a defendant had confessed under the lex Aquilia to wounding a slave but where the slave hadn't actually been wounded, and when Gaius (Institutes III.218) refers to the debate about whether the term 'highest' (i.e. the highest value within the 30 days...) should be read into the third chapter to make it conform with the first chapter, ${ }^{44}$ they are not necessarily indicating that the 30 days are to be reckoned from the wrong backwards in time, but simply referring to the necessity for a judge to be able to put him or herself at an approximate point in the past in order to estimate the value (of the thing, the injury) in question. The res means this thing the law understands as 'burnt, broken, spoiled' as well as, at the same time, the estimate of the value this thing will be in the proceedings. In Paul's example, it is not the slave in him- or herself (who exists as a being and who could be given a value as property), but the wound (which in

42 Yan Thomas, 'Res, chose et patrimoine' (1980) 25 Archives de Philosophie du Droit 413-426; Yan Thomas, 'La valeur des choses: Le droit romain hors la religion' (2002) 57(6) Annales Histoire, Sciences Sociales 14311462.

${ }^{43}$ For e.g., Yan Thomas, 'Acte, Agent, Société: sur l’homme coupable dans la pensée juridique romaine’ (1977) 22 Archives de Philosophie du Droit 63-83, at 80-81. Thomas there observes that 'the estimation of quanti ea res est was the essential task of the arbitrator or iudex' and that it was probably on this terrain that the concept of incorporeal thing was born.

${ }^{44}$ Unfortunately the case itself for which Sabinus apparently responded in the positive was not retained in Gaius's text. 
that case doesn't exist - regardless of the confession - and therefore can't be valued at all). ${ }^{45}$ We can see through this contemporary debate just how far the reliance upon modern economic and metaphysical paradigms can tend to force and distort rather than explain the meaning of the legal text, and also just how far the casuistic method in general and the technical jurisprudential register of res in particular remarkably insulates the bees from a commonplace naturalistic or liberal-economic view of their value.

\subsection{Several bees or a full swarm: the bees as a jurisprudential diagram}

We can return to the chief concern of the meaning of the fragment in question with a closer appreciation for the peculiar way in which the facts of the case are grasped and rendered by the jurist and the distance and ambivalence with which these facts are held with respect to the articulated 'rules'. Frier subjects the whole arrangement of the text, if not to a naturalistic image of the bees, then at least to the grammar of commonsense and to the necessities of the economic and social contexts. He has a typical case in mind: a beekeeper's bees have flown off in search of pollen onto the property of his neighbour who destroys them. Based on that typical case, it becomes possible to alleviate the ambiguity in Ulpian's bees which are flying simply from mine to yours. The first thing that has gone unstated, from Frier's viewpoint, is that - despite the insignificance in monetary terms that such an action would represent - the said bees must not be a full swarm but just one or two individual bees. As Celsus must have been aware - swarming bees are not inclined (like doves) to return to their home and therefore to their owner. They swarm precisely in order to find and establish a new colony elsewhere. This means that, for Frier, 'to yours' does not indicate some mixing of bee swarms (mine and yours). ${ }^{46}$ Rather he suggests that a word has gone missing. The

\footnotetext{
${ }^{45}$ Even where the precise value of the slave can be given, the evaluation of the res under the lex Aquilia always follows a procedural rather than an economic logic. See for example Digest 9.2.55 where A had promised to transfer to Titius one of either of his two slaves Stichus (worth 10,000) or Pamphilus (worth 20,000) and before the agreement could be carried out Titius killed Stichus. In the case of an action under chapter 1 of the lex, Stichus is deemed to be worth the higher value of the two (i.e. the loss that he represents in the proceedings rather than the individual value he had as a slave), even if Pamphilus himself died without fault and therefore A was discharged from his obligation, so long as Stichus was killed within a year of Pamphilus's death.

${ }^{46}$ It would be interesting to consider how far such a misreading of the Roman law influenced the drafting of the present day German Civil Code which includes four rarely used sections (961-964) dealing solely with the unique legal situation of the ownership of bees, including a whole discussion of the combinations and permutations concerning the merging and intermixture of bee swarms.
} 
bees, the text should read, are flying to your trees or to your property. In Frier's view, it is necessary to reinsert these missing pieces in order to make the formulation of the rule more cogent, the description of the facts more accurate and the text more readable. ${ }^{47}$

However, as I have suggested, it is possible that what we are missing is not necessarily the elements of a mis-transcribed or interpolated text, but the key to a conception of jurisprudence - a creative practice of the law - that animates the jurist and renders the peculiar truncated formulation that we find in the text into a more necessary mode of expression. It is here that one encounters the bees as what I would call, to borrow a term from Deleuze, a jurisprudential 'diagram': an outline defined less by identity or resemblance in the represented object or Idea than by the set of concrete functions, problems, relations of thought that can be associated in it and taken further. ${ }^{48}$ Whereas Frier may place his focus on what would make the statement of the principle more logical, the factual situation referred to more typical or plausible, the rule contained in it more clear and certain, from another perspective one might also look for what constructions the jurist is capable of making out of his cases, and what remodelling of the facts, like some casuistic calibration of tools, is necessary to conduct the test.

Let's consider the two formulations in the fragment: 'my bees have flown to yours' and 'your burn them'. These may make clearer sense when we emphasise the narrowness of the basic legal point that is in question: the extent of what can be considered to be, for an action under the lex Aquilia, 'burnt, broken or spoiled'. The words 'you burn them' for instance: equally unusual from the point of view of an ordinary description of the facts, is clearly no accident. And it is also separate from the question of whether we can find a suitable explanation for 'burning' bees from the historical record of beekeeping, as Ariana Pretto-Sakmann also admirably explores, seeing it probably as some failure to apply some

\footnotetext{
${ }^{47}$ Frier also notably appears to replace the final word of the Collatio fragment fugiunt with remanent, see Frier, 'Why Did the Jurists Change Roman Law?' (n 5), 135. Thus, in Frier's reading, the bees, when they 'flee' or 'take flight' from the hand, should actually be said to still 'remain' at home rather than 'flee' or 'take flight' home.

48 For some of the remarks on the notion of 'diagram' and 'diagrammatic' see: Gilles Deleuze, Foucault, translated by S. Hand (Continuum 2006), 30-38; Gilles Deleuze and Félix Guattari, A Thousand Plateaus: Capitalism and Schizophrenia, translated by B. Massumi (Continuum 2002), 141-148. For the critique of the 'dogmatic image of thought' upon which this notion is built see Gilles Deleuze, Difference and Repetition, translated by P. Patton (Continuum 2004), 164-213.
} 
smoke in order to pacify and capture them. ${ }^{49}$ Rather, we can view it - to borrow from Pottage - as a kind of resourceful jurisprudential stenography. ${ }^{50}$ The facts may appear 'surreal or bookish' as Frier describes them, ${ }^{51}$ but they are at the same time the product of an attempt to focus the legal analysis. The bees are 'burnt' because if it were a question of 'poisoning' them as in the 'case of the poor man's bees' described in the thirteenth Major Declamation attributed to Quintilian, ${ }^{52}$ or killing them or driving them away with 'smoke' as in Digest 9.2.49, the effect would be to leave problematised something that is decidedly not intended to be so: whether the act of the defendant was a 'direct' or an 'indirect' cause of the destruction. $^{53}$ The point is that 'burning' comes explicitly within the (already somewhat archaic) terms of the lex Aquilia and is not in question here. Our concern is sharply focused on what sort of ownership or possession, what shape of dominium is envisaged by the terms of the statute. It is on this focused legal terrain that the bees are meant to enter the picture.

It is a short step from there to acknowledge the technical work that the other oddly formulated words of the passage ('my bees have flown to yours') perform. It is apt for the jurist to emphasise that we are not dealing with the same question as - as mentioned above whether one has ownership in general over such things as wild animals and bees in particular. It is not technically about whether another person can validly claim them as their own when they have flown away from your direct control. The concern is narrower. It is about the precise form of ownership or possession or control that is capable, under the terms of the lex, of being subject to the infliction of such unlawful damage (damnum facere) as 'burning, breaking or spoiling'. The peculiar tightness of the phrase makes better sense when we acknowledge the supple and provisional - the 'concrete and associative' rather than

\footnotetext{
49 'In all probability,' Pretto-Sakmann, concludes, 'the ad tuas text is a case of a swarm taking off, thus losing its animus revertendi. A neighbour rather inaptly tries to use smoke to pacify the swarm and capture it, or take the honey. The attempt at pacification fails. Fire and destruction ensue.' Pretto-Sakmann, 'You Can Never Tell With Bees' (n 27), 494. Smoke is mentioned by Ulpian in relation to killing bees in Disputations, book 9 (Digest 9.2.49) as not falling under the lex Aquilia since it appears 'to have provided the cause of their death' and not 'to directly to have killed them.'

${ }^{50}$ Pottage, 'Law After Anthropology' (n 6), 156.

${ }^{51}$ Frier, 'Why Did the Jurists Change Roman Law?' (n 5), 143.

${ }^{52}$ Lewis A. Sussman (ed), The major declamations ascribed to Quintilian: a translation (Peter Lang Gmbh 1987), 165-176.

${ }^{53}$ This point is made by Dieter Nörr. See Dieter Nörr, Causa mortis: Auf den Spuren eine Redewendung (Beck 1986), 193.
} 
'schematic and rigid' - nature of the thought of the jurist. ${ }^{54}$ There is something that can afford to be bracketed out in the economy of the treatment: that is precisely the question 'what form of ownership does one retain and acquire in bees?' The interpretation would not be enriched very much if one were to go from what would be a dogmatic position on this point in one area (they remain ours so long as...) to a solution which is based on that same dogmatic position applied to the lex Aquilia (they can be considered property subject to being unlawfully 'burned' etc). The jurist would rather discover the technical terrain upon which the precise question enclosed in the case - with all the legal subtleties in play - can be adequately encountered, than to subject both the case and the prior jurisprudence to the dogmatism of an abstract rule. This thought of law extracts from the figure of the bees, as mentioned, a certain diagram - an abstract set of juridical relations and a distinct jurisprudential meaning - and puts it to work to sharpen its focus.

They have simply 'flown to yours'. Even if it remains difficult to picture the whole distinct factual scenario alluded to here, we can understand something of the necessary juridical precision involved. The jurist is at extreme pains to avoid intruding, in a roundabout way, into an issue that strictly does not belong to the jurisprudence on the lex Aquilia. In just a few words, we are capable of hearing all of something like: 'did you know that there is debate about whether bees remain yours when they fly away from your hive? We're not concerned with all the detail of that controversy here as it concerns that area of the law about possession and occupation. It suffices to say that when the lex Aquilia provides an action for property that is burned, broken or spoiled, Celsus's view is that it includes even this somewhat tenuous form of property that one retains in bees however one might want to qualify it.' Are we supposed to surmise that they have flown to and merged with some bees that you already own, before you burnt them? That they have flown onto your property? To your trees? Are we supposed - in order to understand the law as it is described - to picture a clear and distinct factual basis to the case? To extrapolate that the bees must not be a full swarm but only several individual bees, since otherwise they would not have the inclination to return? These concerns are actually beside the point. The crucial thing from theperspective of the jurist is that any of these terms tends to already say too much for the rigour of the analysis it demands: it sets one on an inquiry into facts that are not strictly required and which don't help to distil the question of law. The suggestion by Pretto-

\footnotetext{
${ }^{54}$ Finkenauer, 'On Stolen Swine, Fished Fisherman, and Drowned Dogs' (n 4), 42.
} 
Sakmann, that ad tuas can be 'explained as a metonymy: a mention of bees for where bees reside, and thereby a reference to "land" or "property" is elegant enough. ${ }^{55}$ But the bees should also not be denied the bare shape they have acquired in jurisprudence: a shape which is diagrammatic more than figurative. Not an analogy in thought but a tool for extending it. Property is precisely what is in question. The reference to the bees serves a double purpose: it covers in one sense the actual animals themselves in so far as they are relevant to the case, and it also describes the distinct mode of possession or property which is elastic or amorphous enough to be capable of being extended from 'mine' to 'yours'. In this way the bees can offer a distinct diagram for interrogating the ownership or possession of things for which the lex Aquilia imagines reparation for unlawful harm, without enclosing the animal in any naturalising discourse, and without foreclosing anything in the lively casuistry, the set of cases, in which ownership in wild animals can supposedly be lost by one and acquired by another.

\section{Analysis II. A test of the subject of right. Two temporal diagrams in Digest 45.3.18.2.}

\subsection{A slave whose owner had been taken prisoner by the enemy stipulated for payment to his owner...}

Let's now consider a second passage: one which concerns the activity of the jurist in the form of argumentation in the case more than just the description of the facts upon which it is constructed. It would be interesting to ask whether we should read this second fragment as being a touch wordy or rather exceedingly concise? Whether the reasoning is relatively superfluous or remarkably precise? Whether it unnecessarily obfuscates the juridical principles involved or whether it rather refines and perfects them to an exceptional degree? The passage reads as follows:

A slave whose owner had been taken prisoner by the enemy stipulated for a payment to his owner. It is true that what he stipulates for without qualification or receives

\footnotetext{
${ }^{55}$ Pretto-Sakmann, 'You Can Never Tell With Bees' (n 27), 494.
} 
from another belongs to the prisoner's heir, and that the law is different in the case of a stipulation by his son, because he would not have been in power at the time when he stipulated, nor would he later, like the slave, form part of the inheritance. However, in the present case, it may be asked if the heir should be deemed to get nothing from this stipulation, just as where a slave of the inheritance has stipulated for the deceased or even for the future heir. But in this case, the slave will be put in the same position as the son; for if the son stipulates for a payment to his father who is a prisoner, the matter will be in suspense, and if the father dies in captivity, the stipulation will be regarded as of no effect, since he stipulated not for himself but for another. ${ }^{56}$

Alan Watson provides an interesting commentary on this passage in an article titled 'Thinking Property at Rome'. ${ }^{57}$ Watson observes something in the text which, as in our first example, could be seen to be a certain awkwardness in the jurist's formulation. The immediate problem that the passage concerns, as Watson reconstructs in his article, is the following. A slave stipulates or enters a contract with another party for payment to be made specifically to his owner ('Aulus'). ${ }^{58}$ However, before the stipulation was made, the owner of the slave had been taken prisoner, becoming in effect a slave of the enemy and losing any rights he had held as a Roman citizen. The validity and effect of the slave's stipulation is therefore in doubt. According to the Roman law of postliminium, while the owner is in captivity this owner is actually in a legal state of suspense: for when he dies in captivity the law treats him fictitiously for inheritance purposes as having already died as a free man before being taken prisoner in order that his estate can validly pass to his heirs, while when he returns (honourably) from captivity, he is considered fictitiously to have never been taken prisoner, so that he is restored effectively to his full legal powers, obligations and property rights. The difficulty addressed in the fragment, as Watson clarifies, is whether this stipulation, which was specifically for payment to the captive 'Aulus', can still be taken to benefit Aulus's heir. If Aulus returns, then one could say that his contractual rights revived

\footnotetext{
${ }^{56}$ Digest 45.3.18.2 (Papinian, Questions, book 27). The English translation is the one provided by Susan Hart, Andrew Lewis and Ben Beinart in Watson's edition.

${ }^{57}$ Alan Watson, 'Thinking Property at Rome' (1993) 68 Chicago-Kent Law Review 1355-1371, at 1363.

${ }^{58}$ A stipulatio is a basic form of verbal contract made in the form of a question and answer ('do you undertake?'

- 'I undertake' etc). Roman law recognised slaves as capable of entering into many kinds of legal dealings that were held to benefit, and in certain circumstances also to bind, their owners. W. W. Buckland, The Roman Law of Slavery (Cambridge University Press 1908), at 131-158.
} 
retroactively and the stipulation was valid in his favour. But if he died in captivity, what then? Are we to suppose that those rights pass to his heir as if he hadn't fallen into captivity in the first place? Or rather are we to say that these rights are stranded in the verbal form that created them, which by mentioning Aulus specifically, consigned them to follow the fate of this individual person?

Watson observes with interest the avenues by which Papinian addresses this 'tricky issue', ${ }^{59}$ coming to the inference nevertheless that these avenues express only a measure of despair on the part of the jurist in searching for a suitable path to the right solution. 'The text seems rather confused,' Watson writes, 'but the thought process can be recovered'. ${ }^{60}$ It consists, he says, in taking 'two standard approaches together'. ${ }^{61}$ The first approach considers the simpler scenario, where the slave had not stipulated for 'Aulus' but had done so generally or without qualification - i.e. in the form 'do you promise to give to me?', 'I promise'. This case of the unqualified stipulation is simpler because, as Watson suggests, in that scenario 'the slave acquires the rights for his owner even if who the owner is cannot be determined at the moment'. ${ }^{62}$ The stipulation attaches in effect to the person of the slave who, as part of the inheritance, passes freely from one owner to the next. The second approach Watson calls 'the approach by analogy': the consideration of the position of the filius-familias, the son-in-power. To what extent is the position of the slave who stipulates for his master equivalent to that of the son-in-power who stipulates for his father, his paterfamilias? Papinian himself acknowledges here however that the two are not equivalent when it concerns the unqualified stipulation. Unlike the slave, when the son-in-power stipulates in the form 'do you promise to give to me?', 'I promise', the death of his father in captivity means that the stipulation is treated not as part of the inheritance but as valid in favour of the son himself as sui iuris (legally independent). '[N]either of these two approaches,' Watson finally observes, 'turns out to be fruitful.' ${ }^{63}$ The first 'provides no guidance for the difficult alternative', while 'the analogy with the son also breaks down' in relation to the unqualified stipulation. ${ }^{64}$ Watson is left to observe Papinian's resignation

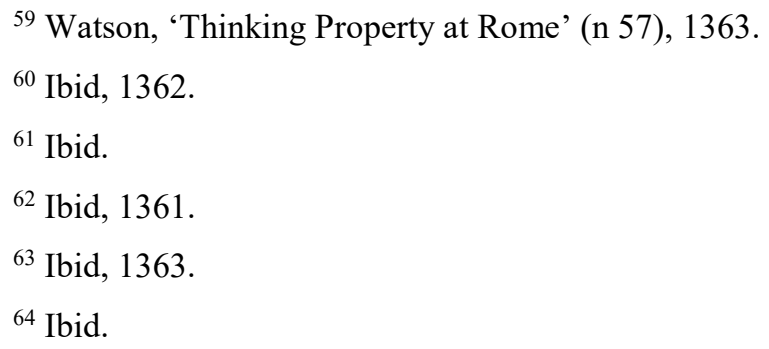


before the hard case which can be resolved at the end of the fragment only by 'cut[ting] the Gordian knot' and resorting to the mere assertion that the analogy to the son-in-power does indeed work for the complex case 'even when the owner died a prisoner!' 65

\subsection{The case thinks the law: non-subsumptive contours of jurisprudence}

The whole picture painted by Watson of the thought of the jurist as it is reflected in this fragment is framed by a view of what I would call an 'subsumptive' model of legal science: a paradigm that considers the work of jurisprudence to be aimed at conquering the frontier of difficult cases under the domain of more general, more abstract, more universal principles. Failing to find a solution to the problem through the two lines of reasoning adopted, Watson suggests that the elegance of Papinian's analysis is not what it might have been. From this purely subsumptive viewpoint, we can see why. The case represents only a vain search for a solution to a difficult problem. The jurist, Watson's analysis seems to assume, is in the business of reaching toward principles adequate to the cases at hand. In this way, we see the bulk of the text as largely superfluous: the retention of the steps of the mere 'mental workings' of the jurist that, having been ultimately fruitless in terms of leading to a solution, might have been better left out of the picture entirely. Papinian, Watson concludes, 'might have used a more direct approach ... which would have been at least as persuasive and would have given the same result'. ${ }^{66}$ All of the discussion of the case of the son and of the 'simple' case of a stipulation made without qualification could, in his opinion, just as easily have been removed.

Now, this perspective I believe clouds an important part of our view of the craft or expertise of the jurist and the significance that the 'case' has in that craft. As far apart as Watson is from a scholar such as Frier in terms of, to borrow Watson's words, their 'understanding of how law develops in society' ${ }^{67}$ - either in a fundamentally contextualised way, driven by social and economic forces, or as the result of an inward-looking legal culture often divorced from social context - there nonetheless appears to be a common assumption behind their work. If the jurist has an interest in cases, it is supposed to be only in order to demonstrate and articulate a world of more universal rules and principles, striving to equip

\footnotetext{
65 Ibid.

66 Ibid.

${ }^{67}$ Alan Watson, 'The Birth of the Legal Profession' (1987) 85 Michigan Law Review 1071-1082, at 1082.
} 
these rules with a generality that would allow all further cases to be adequately adjudicated. Thus when one finds the description of the facts of a case consciously or unconsciously remodelled or when one finds the path to the general rule that the jurist follows to be deliberately or inadvertently diverted without other explanation, it is easy to dismiss these as errors affecting a more regular jurisprudential activity and to forget the peculiarities of an art that elsewhere has an appetite only for refining the cases, and for stretching the both the facts and the rules through the unique institutional prism that these cases, these chance-encounters present. We still expect from the words of the jurist, the legal expert, a line that takes us from the general to the particular in the most direct and persuasive way as possible: for the uncertainties and contradictions of law to be adeptly reconciled, abstract principles arrived at, through the weight of coherent reasoning and systematic analysis. Yet if we suspend this expectation for a moment, we can perhaps notice more clearly the area in which the craft of the jurist operates with a firmer independence: not necessarily on the world of principles and solutions which are capable, owing little to legal science, of being formulated, applied, raised to the level of authoritative and generalised norms, but on the world of received institutional categories and arrangements which are to be honed and perfected, tested and extended, by careful technique. To arrive at principles, we find, is a commonplace. What is unique is the case which, in the creative hands of the jurist, becomes itself capable of thinking the institutional limits of the law.

Positioned in this way, the case finds itself in the midst of quite a different set of concerns: an array of fictions and expedients that the Romans produced to deal especially with the problems that periods of captivity posed for the law and a set of techniques that went to extraordinary lengths to repair a whole range of temporal discontinuities thrown up by such circumstances. It is these moments of fiction and invention, more than anywhere else according to Thomas's reading of the Roman tradition, ${ }^{68}$ that allow us to glimpse the operation of the law in its independence: the radical separation that it introduces between itself and an objective reality, even while it tries to attend more closely to the contours of its 'cases'. What is striking from this point of view is not necessarily the ineffectuality of the

\footnotetext{
${ }^{68}$ See especially Thomas, 'Fictio legis' (n 11); Thomas, 'Les artifices de la vérité en droit commun médiéval' (n 13); Yan Thomas, 'L'enfant à naître et l' “héritier sien”: Sujet de pouvoir et sujet de vie en droit romain' (2007) 62(1) Annales Histoire, Sciences Sociales 29-68; Yan Thomas, 'Le cas limite et l'extrême urgence, du fait au droit' in L'exception dans tous ses états, series “Savoirs à l'oeuvre” (Editions Parenthèses 2007), 209-223.
} 
two avenues of reasoning pursued in Papinian's text, but the refusal that these avenues represent to call upon a much broader range of technical analogues that we can assume were at the jurist's disposal and may have offered themselves as figures for the solution to the case at hand. There is no direct recourse for instance to the fictions of personification that allowed Marcellus and Julian to hold the stipulation of a slave of a vacant inheritance to be valid 'by virtue of the personality of the deceased' in Digest 41.1.33.2, or in Digest 41.3.15 where a period of captivity is held, in favour of the heirs, not necessarily to interrupt the matter of continued possession since 'an inheritance is in certain respects held to perform the office of the person of the deceased'. ${ }^{69}$ There is also no conscious reference - relevant to the transaction of the son-in-power - to the controversies that obviously existed for Gaius to note in his Institutes I.129 that while the children of a father who dies in captivity will become sui iuris, there is doubt whether they should be considered to have become so at the time of their father's death in captivity or rather, retrospectively, at the time of the capture. ${ }^{70}$

While the examples could be multiplied without offering a complete answer to the problem, it is nevertheless with them in mind - situations in which the Roman jurists really delighted in sharpening their interpretive energy especially when it was a matter of distilling a fictional, institutional time of life and death from a 'real' one - that we can productively approach the sequence of thoughts evoked in Papinian's text: in particular the function of the 'simple case' and the 'analogy of the son-in-power'. These examples aren't just lines of reasoning tried out but ultimately abandoned. They are an attempt to stick more closely to the contours of the case in terms of what it allows us to perceive in the institutions of the civil law. Instead of picturing the jurist trying to 'deal' with the case by subsuming it under existing legal categories, we should instead imagine that it is the case itself that thinks the categories within the specialising reflections of this 'connoisseur' of law, the jurist. As James Gordley paints in his portrait of this figure, the 'strikingly original' innovation of the jurist is

\footnotetext{
${ }^{69}$ I have diverted from the translation by J. A. C. Thomas of Digest 41.3 .15 in Watson's edition here by preferring for the Latin fungi the English 'perform the office of' rather than 'represent'. On the significance of the slippage between the terms fungor and fingor in the medieval reception of Roman law for the idea of legal personality more broadly see Thomas, 'Le sujet de droit, la personne et la nature' (n 17), at 100-101.

${ }^{70}$ On this point W. W. Buckland notes that the general principle appeared to favour Papinian's solution: that these transactions were in a state of suspense. 'But,' he adds, 'it is clear that this rule is a gradual development, which in some parts of the law is far from complete: in some, indeed, there is no trace of the rule of suspense; the captivity ends the right.' Buckland, The Roman Law of Slavery (n 58), at 292.
} 
not in the creation of a 'set of rules or principles' or a 'systematic doctrinal structure' but in a method that refines concepts by 'putting particular cases'. ${ }^{71}$ It is the case, on its own, that contains the whole apparatus. If it is necessary also to reach a solution to it, Papinian appears not so much to want to offer convincing reasons, but to want to clear the ground. First of all, the solution (convincingly argued) risks being mistaken for the existence of an abstract general rule when in fact it is only intended as a kind of stop-gap in a science that acknowledges its own boundedness to the pragmatics of decision. Secondly, the jurist wants to treat the case itself and its solution as the opportunity to neatly and uniquely isolate certain juridical paradigms, certain institutions, diagrams of right - treated not like products of his own creation, but like real beings with whose 'existence and genealogy', as Savigny famously described, ${ }^{72}$ he claims an intimate acquaintance. The unconventional path that is sometimes taken in the reasoning of jurist attests to the fact that what is sought to be secured is not necessarily a solution to the problem but the singularity of the problem itself for the thought of law.

\subsection{Two temporal diagrams: the time of the inheritance and the time of the stipulation}

With this in mind, we can point to at least two juristic diagrams that Papinian isolates in his neatly constructed case, each with a particular temporal arrangement the subtlety of which he attempts to hold in play. The first is what we could call the time of the inheritance: the time in which the stipulation is transmitted as part of the inheritance. We see the simple case being introduced here, by way of contrast to the complex case, not necessarily as an attempt at simplifying the problem so much as a means of casting light on the flexibility of the institutions in question. With the doctrine of postliminium, the stipulation of the slave comes to occur in a kind of legally ambivalent time for the purposes of inheritance. When the owner dies in captivity, his death is pushed back to the time of his capture; when he returns from captivity, it is as if he had never fallen into slavery. According to this paradigm, the jurist tells us, when this owner's slave stipulates generally, the validity of this stipulation is unaffected by this particular temporal ambivalence. What the slave acquires he acquires for his owner, whoever that may be. And since the slave is himself part of the inheritance, the stipulation follows freely from one owner to another regardless of the discontinuities in

\footnotetext{
${ }^{71}$ James Gordley, The Jurists: A Critical History (Oxford University Press 2013), at 18.

${ }^{72}$ Friedrich Carl von Savigny, On the Vocation of Our Age for Legislation and Jurisprudence, translated by A. Hayward (The Lawbook Exchange 2002) [Originally published 1814 in German, 1831 in English], at 45.
} 
time raised by captivity and the ambiguities over the identity of his 'owner'. It is as though this transaction of the slave, like the slave himself, can be thought to follow the precise time in which the patrimony is transmitted from one owner to another, however abstract that time may be in the imagination of the law and despite all the fictions involved in the juridical conception of the transmission. Since the slave is himself part of the inheritance, it doesn't matter that the stipulation occurs at a certain moment while the inheritance is thought (fictionally) to occur at another: either sometime before or sometime after. Cast in this light, we can locate the difficulty of the complex case more clearly. It is not, as the elasticity of the simple case makes clear, a result of any rigidity in the institutions themselves. It is not, as it might have appeared if Papinian had gone directly to his solution, the case that the 'rule of suspense' operates like a constraining maxim. The institutions remain plastic, deformable. In the simple case, the abstractness in the form of the stipulation ('Do you promise to me', 'I promise') meets, point for point, the polyvalency in the time of inheritance. This leads one only more carefully and perceptibly to what seems like the one exception (in the complex case), which is encountered now as an impasse requiring its own makeshift solution, rather than as a sclerosis of the institution itself.

There is another half to the picture. Papinian also uses the case to isolate a second diagram: the time of the stipulation or the time of the emergence of the subject of the stipulation. It is here that the example of the son-in-power becomes crucial. Why is it necessary to refer to the situation of the son? In a way, it is not just a question of the stipulation following the trajectory of the inheritance in which it falls (as the first diagram outlines). It is also a question of it following the trajectory of a subject in whose right it emerges and in whose person it can be actioned. On the one hand, the problem of determining the claim of the heirs is a matter of dealing with the essentially uncertain time in which the transmission of the inheritance can be thought to occur in the case of captivity. Here, as we saw, the example of the simple case said enough: the inheritance itself (including the slave) may pass - in its fictional and deformable temporality - from one owner to another. But the example of the son-in-power is needed to address, on the other hand, a further dimension. It is only for the son that we must consider the time in which the one who stipulates exists under the power of his dying father (something foreign to the slave) in order to imagine his emergence as a full subject of right. According to a concept at least as old as the Twelve Tables (450 BC), it was only upon the death of the father under whose power of life and death he or she was at the time that an individual ultimately became an independent 
subject of right (sui iuris). The jurist doesn't want to leave this side to the picture unaddressed: the fact that the right (the benefit of the stipulation) doesn't just attach to a preexisting individual, but to a subject that him or herself emerges from the very institutions in question.

Circumstances of captivity indeed provided one of the most fertile terrains on which these contours of legal subjectivity could be probed by the jurists. It required them, with all their ingenuity, to construct fictionalised presentations of time - artificially folding or stitching up imagined intervals - in order that sons could be considered (despite the period of captivity) to have lived under the power of their dying fathers (in potestate morientis), and allowing them to still succeed to the estate as proper heirs. ${ }^{73}$ An array of figures were used to think this radical immediacy of succession: a 'quasi-identity of the subjects united by the process $^{74}$, 'the fiction of identity of the living and the dead' ${ }^{75}$, or the observation by Paul (Digest 28.2.11) that in fact it appears as if no succession actually takes place, just the son acquiring free administration of an estate that was in a way already his own. ${ }^{76}$ These formulations, importantly, were far from metaphysical postulates incorporated into the shape of legal concepts. They were attempts to accord, in an expedient and provisional way, with their traditions and with the precision that their juridical language demanded to describe a power that transmits itself and a legal subjectivity that emerges in a fundamentally continuous dimension.

It is no exception in the fragment from Papinian. The jurist appears acutely aware of the importance that the casuistic problem attaching to the captive owner or paterfamilias represents for charting the institutional contours of the subject. The case poses the question of whether the heirs would have a claim to the benefit of the stipulation when the owner was already in captivity when the stipulation was made. But in whose right is this stipulation made? Papinian needs to introduce the difference between the situations of the slave and that of the son in order to emphasise the difference that the death of the prisoner would make on this question. When the slave stipulates he does so only as an accessory to the right of his owner. When the son-in-power stipulates it is almost as if he is already an owner in the

\footnotetext{
73 Thomas, 'Les artifices de la vérité en droit commun médiéval' (n 13), 113-130.

74 Thomas, 'L'enfant à naître et l' "héritier sien”' (n 68), at 54.

${ }^{75}$ Ibid, 56.

${ }^{76}$ Ibid, 48.
} 
lifetime of his father. This is why Papinian says that what matters formally in the case of the son is not so much whether he has stipulated generally or specifically, but whether he has stipulated for himself or for another. The death of the captive father may be pushed back in time fictitiously by the law in order precisely for the son or the heirs to validly succeed to the inheritance. But it cannot correct the defect in the form of a stipulation made by the son which - naming his father - cannot be treated at that time as returning to a full legal subject: someone who acts in their own right and not in that of another. The whole right does not return to the same person (with or without personifying the estate). No subject of the right emerges until this father returns with postliminium.

Papinian allows the position of the slave to emerge more clearly then, in the context of the institutions that the case as a whole calls into question. What Watson sees as two fruitless modes of reasoning around a hard case, are in fact two technical diagrams which, once in place, help deepen the legal thought embedded in the case and also help qualify the narrowness and provisionality of the final makeshift solution to it. When the fragment gives us its solution - the equiparation of the slave with the son - it arrives with the necessary precision and qualification that the jurist apparently considers it demands. He gives us the depth of the juridico-institutional distance separating slave and son in relation to the captive owner or paterfamilias, in order to emphasise by contrast the limited and rather provisional way in which they are to be presented treated as alike.

\subsection{Invention and experimentation}

To read the fragment in Digest 45.3.18.2, one can afford to look past the rigid outer shell of its dogmatic reasoning. 'The peculiar manner in which legal science is presented,' Fritz Schulz once observed, is that it doesn't try to 'prove the rules stated'. ${ }^{77}$ What Watson tends to see as a deficiency and confusion in the text - the inability ultimately to illustrate the legal rule or principle by way of the analogies it has recourse to - can in fact be viewed quite differently. The jurist doesn't intend to go from the hard case to its conclusion by way of a reasoned and systematic argument let alone by a universalisable legal-philosophical vision. The articulation of the case on the one hand and its solution or solutions on the other, more often than not arrive hand in hand, the jurist moving between them 'all at once' ${ }^{78}$ with

\footnotetext{
${ }^{77}$ Schulz, Principles of Roman Law (n 3), at 35.

${ }^{78}$ Gordley, The Jurists: A Critical History (n 71), at 8.
} 
minimal explanation and with little 'theoretical deduction'. ${ }^{79}$ The skill instead seems to be to shape this whole problematic of the case into a kind of test, an experiment - not of the immediate point at hand - but of the institutional dimensions of the civil law. It is not a question of rationalising institutions, but of inventing and extending them. It is not a question of extracting higher principles to which the piecemeal fictions of legal institution could be referred, supposedly putting the law on a surer path in relation to truth, reality, the universal, but of pushing the piecemeal nature of legal institution further, attending carefully to its fictions, isolating the singularity of the cases to which they belong, and putting them all in the service of a more precise vision of the law. Viewed from this point of view, the comparison to the simple case and the reference to the situation of the son-in-power are essential. These short added outlines focus attention in a very direct way on the nature of the juridical problems which it is necessary in this instance precisely not inadvertently to sweep away or to provide a solution that proves too general, and therefore around which the jurist makes a point of having to tread very carefully, avoiding foreclosing anything of the lively jurisprudence that the problem comes into the vicinity of.

\section{Conclusion}

In each of the two cases and passages that I have analysed here, there is a common thread. We see an economy and a peculiarity of expression within each of them: a remarkable conciseness, easy to mistake for awkwardness, that is not just about a clear and uncomplicated description of the facts of the particular case, or about finding the more direct and convincing argument that would take us from this case to the rule of law that would resolve it. Instead what seems to be revealed, if we can take the authenticity of the texts at face value, is a willingness to stretch the ordinary description of these factors - the facts and the rule - in order solely to master the juridical categories, problems and institutions and to subject them to the activity of their science. Frier's approach treats the legal concepts as contingent on an underlying social context and certain facts of nature, forgetting that part of the very technique of the jurist is to denature the facts in order to pose and refine the

\footnotetext{
${ }^{79}$ Schulz, Principles of Roman Law (n 3), at 51.
} 
problems of law. Watson's treats the effort of juridical reasoning as an instance of reaching solutions to cases by subsuming them under the strict network of legal concepts and principles, leaving aside that aspect to the casuistic method of the jurist that invites us to treat the case itself as the means by which concepts are thought and extended. In each fragment the jurist doesn't just represent the law concisely and straightforwardly. The sober concision of expression in the work is, instead, a necessary means of 'isolating' it and making it an object of thought. This essay has aimed to follow some directions opened up by the work of Yan Thomas whose depth of encounter with the originality of this activity of jurisprudence in the texts of Roman law, I think, continues to resonate very strongly today. 